\title{
Cisto dentígero em equino
}

Tatiane Faria Prado, Kamila Pinheiro Paim, Raíssa Oliveira Leite, Eriky Akio Tongu, Diego Jose Zanzarini Delfiol, Geison Morel Nogueira*

*Autor correspondente

e-mail: geison.nogueira@ufu.br

\section{Resumo}

Cisto dentígero é uma afecção congênita decorrente de uma anormalidade do fechamento da primeira fenda branquial durante a formação embrionária, geralmente identificado em jovens, na região temporal, podendo ocorrer bilateralmente, sendo pouco comum em equinos. Caracteriza-se por quantidade variada de tecido dentário englobado em estrutura cística revestida por epitélio, que produz uma secreção mucóide que drena por um trato fistuloso. 0 diagnóstico é realizado com base no histórico, exame físico e radiográfico, e o tratamento consiste na excisão cirúrgica do tecido. Dentre as complicações associadas à cirurgia, há o risco de hemorragia, danos ao meato auditivo, traumatismo craniano e lesões neurológicas, como a paralisia de nervo facial. Uma égua, sem raça definida, de pelagem pampa, com mais de 20 anos de idade foi encaminhada para o Hospital Veterinário - UFU após ser apreendida pela Prefeitura Municipal de Uberlândia. 0 animal apresentava baixa condição de escore corporal (2/9), apatia, pêlos opacos e mucosas pálidas. Possuía um aumento de volume nodular, séssil, indolor e de consistência dura, na base do pavilhão auricular esquerdo, com presença de fístula e secreção mucóide esbranquiçada. Ao exame radiográfico tangencial da área acometida, em projeção oblíqua da região temporal esquerda, observou-se área com radiopacidade e contornos bem definidos, próxima à região do meato acústico externo esquerdo, compatível com cisto dentígero. A égua foi submetida à anestesia geral inalatória para ablação cirúrgica da fístula. Durante a ressecção do trajeto fistuloso, pôde-se observar no interior da saculação uma estrutura de coloração branco amarelada e de consistência dura, semelhante a um elemento dentário, medindo 2,7 x 2,0 x $1,5 \mathrm{~cm}$. Foi aplicado um dreno de penrose na região, que foi removido no terceiro dia pós-cirúrgico. Instituiuse terapia antimicrobiana com penicilina benzatina (40.000UI/kg, IM a cada 48 horas, quatro aplicações) e gentamicina $(6,6 \mathrm{mg} / \mathrm{kg}$, IV, SID, por sete dias) e terapia anti-inflamatória com flunixin meglumine $(1,1 \mathrm{mg} /$ $\mathrm{kg}$, IV, SID, cinco dias). Profilaticamente, administrou-se soro antitetânico (10.000 UI, IM) e omeprazol (4,4 
$\mathrm{mg} / \mathrm{kg}$, VO, cinco dias). No pós-operatório, a égua apresentou paralisia de nervo facial do lado esquerdo, caracterizado por ptose palpebral, desvio de lábio e acúmulo de alimento na cavidade oral. Iniciou-se, então, terapia com dexametasona (0,1mg/kg, IV, SID, por três dias), vitamina B1 (10 mg/kg, IV, por três dias) e fisioterapia. 0 animal recebeu alta 55 dias após a cirurgia, com boa cicatrização das feridas cirúrgicas e sem sequelas neurológicas. 0 cisto dentígero, apesar de ser identificado em animais jovens, foi visto nesta égua idosa provavelmente devido ao animal não ter recebido atendimento veterinário prévio. Assim como descrito na literatura, a paralisia de nervo facial foi uma das complicações que ocorreu neste caso, porém a terapia instituída foi satisfatória tanto para o tratamento do cisto dentígero quanto para a lesão neurológica.

Palavras-chave: Cisto odontogênico. Polidontia Heterotópica. Cavalo. 